\title{
Duodenal gangliocytic paraganglioma showing lymph node metastasis: A rare case report
}

\author{
Yoichiro Okubo', Tomoyuki Yokose², Masaru Tuchiya³, Aki Mituda', Megumi Wakayama', Chikako Hasegawa², \\ Daisuke Sasai1 ${ }^{1}$ Tetsuo Nemoto ${ }^{4}$ and Kazutoshi Shibuya*1
}

\begin{abstract}
We describe a case of duodenal gangliocytic paraganglioma showing lymph node metastasis. A 61-year-old Japanese man underwent pylorus preserving pancreaticoduodenectomy to remove a tumor at the papilla of Vater. The section of the tumor extending from the mucosa to submucosa of the duodenum was sharply demarcated, solid, and whiteyellowish. Neither necrosis nor hemorrhage was present. Histological examination confirmed the immunohistochemical identification of three components comprising epithelioid cells, spindle-shaped cells, and ganglion-like cells. Epithelioid cells showed positive reactivity for synaptophysin, somatostatin, and CD56. In contrast, spindle-shaped cells showed positive reactivity for S-100 protein, but not for synaptophysin, somatostatin or CD56. Furthermore, we found lymph node metastasis despite lack of bcl-2 and p53 expression. In addition to the rarity of the tumor, we are describing here the present case suggests the malignant potency of the tumor despite lack of acceptable prognostic indicators for neuroendocrine tumor.
\end{abstract}

\section{Background}

Gangliocytic paraganglioma is a rare neuroendocrine tumor that usually occurs at the second portion of the duodenum, and its ultimate diagnosis requires a histopathological identification of three identical components comprising epithelioid cells, spindle-shaped cells, and ganglion-like cells [1]. This tumor has been regarded as benign in general, but a few cases with lymph node metastasis have been reported which required extensive surgical removal [Table 1]. In addition to the rarity of the tumor, the present case suggests the malignant potency of the tumor despite lack of bcl-2 and p53 expression, which has been known as a marker for malignancy of neuroendocrine tumors [2-5].

\section{Case presentation}

A 61-year-old Japanese man presented with epigastralgia and tarry stool a month before admission. He had history of neither habitual smoking nor irradiation. A gastrointestinal endoscopy revealed a tumor with central ulceration at the papilla of Vater. He was referred to our hospital after an endoscopic procedure for the bleeding.

*Correspondence: kaz@med.toho-u.ac.jp

1 Department of Surgical Pathology, Toho University School of Medicine, 6-11-1 Omori-Nishi, Ota-Ku, Tokyo, 143-8541, Japan

Full list of author information is available at the end of the article
Subsequent examinations in our hospital included upper gastrointestinal endoscopy, magnetic resonance cholangiopancreatography, endoscopic retrograde cholangiopancreatography, and endoscopic ultrasonography, which led to the detection of a tumor at the papilla of Vater that suggested regional lymph node metastasis. A biopsy before the operation suggested a duodenal carcinoid following histological findings and the results of immunohistochemical examination. The tumor cells showed positive reactivity for synaptophysin, somatostatin, and CD56. The patient underwent pylorus preserving pancreaticoduodenectomy with lymph nodes dissection.

\section{Pathological findings}

The surgical specimen, an en-bloc comprising duodenum, bile duct, gallbladder, and head of pancreas, was fixed with $10 \%$ buffered formalin. A solid tumor $25 \times 30 \times$ $25 \mathrm{~mm}$ in size was found at the papilla of Vater whose surface was lobulated and covered by attenuated mucosa showing ulcer formation at the center of elevation (Fig. 1A). The section of the tumor extending from the mucosa to submucosa of the duodenum was sharply demarcated, solid and white-yellowish (Fig. 1B). Neither necrosis nor hemorrhage was present. Sections of paraffin-embedded tissue were prepared and stained with hematoxylin and 
Table 1: Gangliocytic paraganglioma showing lymph node metastasis

\begin{tabular}{|c|c|c|c|c|c|c|c|c|}
\hline Reference & Year & $\begin{array}{l}\text { Age } \\
\text { (years) }\end{array}$ & Sex & $\begin{array}{l}\text { Chief Clinical } \\
\text { presentation }\end{array}$ & Site & $\begin{array}{l}\text { Size } \\
(\mathrm{mm})\end{array}$ & Operation & $\begin{array}{l}\text { Follow up } \\
\text { (months) }\end{array}$ \\
\hline Inai et al. [16] & 1989 & 17 & Male & Hematoemesis & $\begin{array}{l}\text { Papilla of } \\
\text { Vater }\end{array}$ & 20 & PD & NED 32 \\
\hline Hashimoto et al. [17] & 1992 & 47 & Male & $\begin{array}{l}\text { Incidental } \\
\text { findings }\end{array}$ & $\begin{array}{l}\text { Papilla of } \\
\text { Vater }\end{array}$ & 65 & PD & NED 14 \\
\hline Takabayashi et al. [18] & 1993 & 63 & Female & Abdominal pain & $\begin{array}{l}\text { Papilla of } \\
\text { Vater }\end{array}$ & 32 & PPPD & NED 24 \\
\hline Tomic et al. [19] & 1996 & 74 & Female & $\begin{array}{l}\text { Abdominal pain, } \\
\text { vomiting, weight } \\
\text { loss }\end{array}$ & Pancreas & 40 & PD & NED 19 \\
\hline Sundararajan et al. [1] & 2003 & 67 & Female & $\begin{array}{l}\text { Incidental } \\
\text { findings }\end{array}$ & $\begin{array}{l}\text { Second part } \\
\text { of duodenum }\end{array}$ & 50 & PD & NED 9 \\
\hline Bucher et al. [20] & 2004 & 31 & Female & $\begin{array}{l}\text { Anemia, } \\
\text { subclinical } \\
\text { jaundice }\end{array}$ & $\begin{array}{l}\text { Papilla of } \\
\text { Vater }\end{array}$ & 30 & PPPD & NED 44 \\
\hline Wong et al. [10] & 2005 & 49 & Female & Melena & Duodenum & 14 & PPPD & NED 12 \\
\hline Witkiewicz et al. [21] & 2007 & 38 & Female & Abdominal pain & $\begin{array}{l}\text { Papilla of } \\
\text { Vater }\end{array}$ & 15 & PPPD & $N R$ \\
\hline Mann et al. [22] & 2009 & 17 & Female & $\begin{array}{l}\text { Abdominal pain, } \\
\text { vomiting, weight } \\
\text { loss }\end{array}$ & Duodenum & NR & PPPD & NR \\
\hline Present case & 2010 & 61 & Male & $\begin{array}{l}\text { Epigastralgia, } \\
\text { tarry stool }\end{array}$ & $\begin{array}{l}\text { Papilla of } \\
\text { Vater }\end{array}$ & 30 & PPPD & NED 6 \\
\hline
\end{tabular}

NR: not reported, PD: pancreatoduodenectomy, PPPD: pylorus-preserving pancreaticoduodenectomy

NED: no evidence of disease

There are ten cases of gangliocytic paraganglioma showing lymph node metastasis including the present case.

eosin (HE) double stain for light microscopic observation. Histological examination showed that a large body of the tumor was present in the submucosa and invaded a part of the muscularis propria, but the bile duct and pancreas were not involved. Histological observation also revealed that the tumor consisted of three identical cellular components: epithelioid cells, spindle-shaped cells, and ganglion-like cells. Tumor cells of an epithelioid cell type usually nested and had a round to oval-shaped nucleus with an inconspicuous nucleolus, as well as a clear and eosinophilic cytoplasm (Fig. 2A). Tumor cells of a spindle-shaped cell type encompassed the nests of epithelioid cells with alignment of a single cell layer and had an elongated and plump nucleus, including an attenuated eosinophilic cytoplasm (Fig. 2A). Tumor cells of a ganglion-like cell type were rarely seen and had a round nucleus with conspicuous nucleolus, as well as a polyhedral amphophilic cytoplasm (Fig. 2B). In addition to the absence of mitosis among these cells, neither necrosis nor hemorrhage was found. However, tumor cells of an epithelioid cell type showed regional lymph node metastasis (Fig. 2C and 2D).

\section{Immunohistochemical findings}

Several kinds of antibodies were used to evaluate and identify tumor cells immunohistochemically. Tumor cells of both epithelioid and ganglion-like cell types showed positive reactivity for synaptophysin, somatostatin, and CD56 (Fig. 3A, B, and 3C). In contrast, the spindleshaped cell type showed positive reactivity for S-100 protein (Fig. 3D), but not for synaptophysin, somatostatin or CD56. Neither cell type was positive for chromogranin A (Fig. 3E), cytokeratin AE1/AE3 or epithelial membrane antigen (EMA). MIB-1 (Ki-67) labeling index estimated less than $1 \%$ in both primary and metastatic foci. Tumor cells invade into the lymphatic lumen which can be recognized by an enclose of podoplanin (D2-40)-positive endothelial cell (Fig. 3F). Tumor cells of the epithelioid cell type metastasizing at the lymph node showed positive reactivity for synaptophysin (Fig. 3G). No tumor cells of the spindle-shaped cell type were found in the metastatic focus as confirmed by the lack of S-100 proteinpositive cells (Fig. $3 \mathrm{H}$ ). Furthermore, tumor cells of the epithelioid cell type in both primary and metastatic foci showed negative reactivity for both bcl-2 and p53 in the present case (Fig. 4A, B, C, and 4D). 


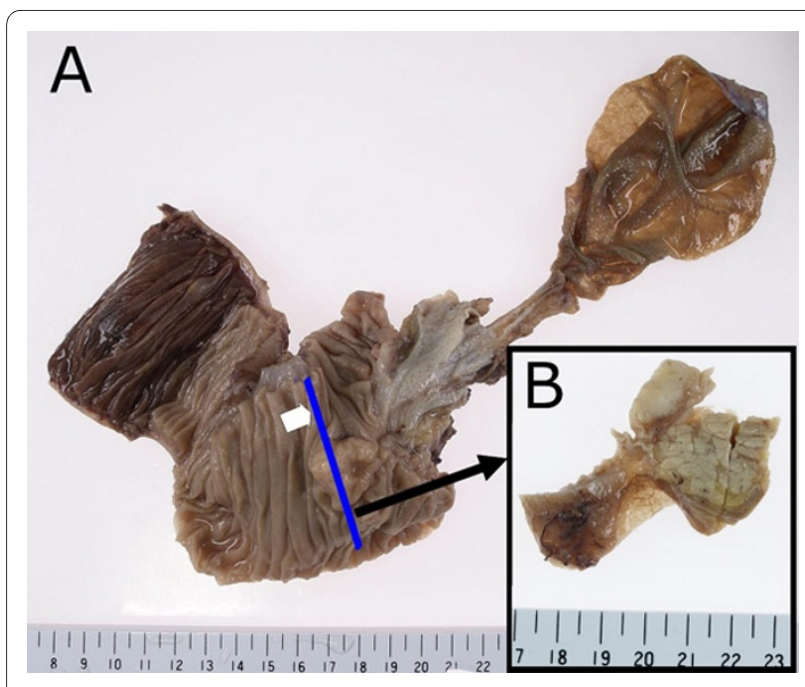

Figure 1 The surgical specimen. (A) A solid tumor measuring $25 \times 30$ $\times 25 \mathrm{~mm}$ in size was found at the papilla of Vater which was lobulated and covered by attenuated mucosa with ulcer formation at the center of elevation. (B) The section of the tumor extending from the mucosa to submucosa of the duodenum was sharply demarcated, solid, and white-yellowish.

\section{Discussion}

Gangliocytic paraganglioma has been known as a rare and benign neuroendocrine tumor. This condition occurs at the gastrointestinal tract, especially at the second portion of the duodenum [1]. Major clinical symptoms of the disease include abdominal pain, nausea, vomiting, and gastrointestinal bleeding. Biliary obstruction has rarely

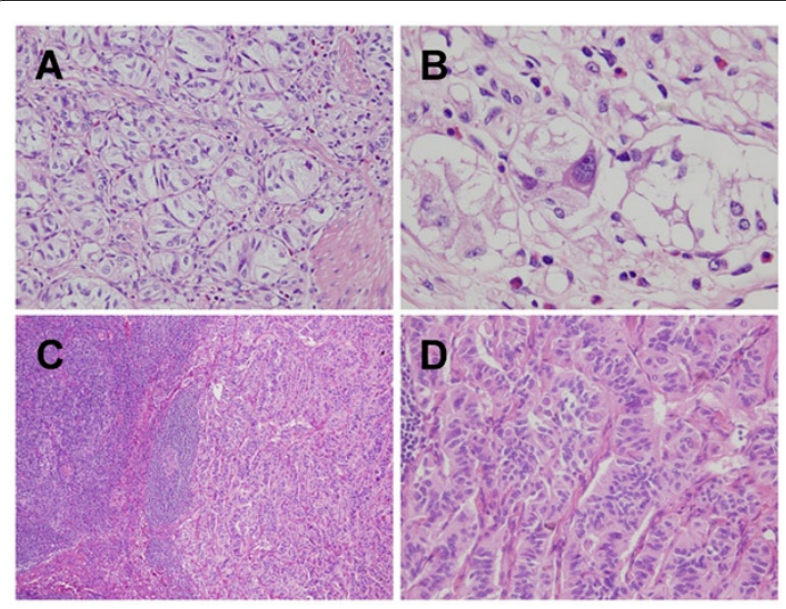

Figure 2 Photomicrographs showing different types of tumor cells. (A) Tumor cells of epithelioid cell type are usually nested which are encompassed by those of spindle-shaped cell type with alignment of a single cell layer (HE double stain, $\times 400$ ). (B) Ganglion-like cells; third type of the tumor cell had a large and oval nucleus with conspicuous nucleolus, as well as a polyhedral amphophilic cytoplasm (HE double stain, $\times 1000)$. ( $C$ and D) The metastasizing component of the tumor at the lymph node comprised the epithelioid cell type alone (HE double stain, $\times 100, \times 400$, respectively). been reported as a devastating complication [6,7]. Histopathological diagnosis of the disease should require a confirmation of three identical components comprising epithelioid cells, spindle-shaped cells, and ganglion-like cells [1,6-8]. Carcinoid tumor, paraganglioma, ganglioneuroma or spindle cell tumors (including nerve sheath tumors, smooth muscle tumors and gastrointestinal stromal tumors) should be referred as diseases for differential diagnosis in cases of histopathological investigation [6]. To identify the three cellular components, in addition to the detailed microscopic examination of hematoxylin and eosin double stained sections, phenotypical expression analysis by immunohistochemical examination has been regarded as an important diagnostic clue $[8,9]$. Although gangliocytic paraganglioma has been regarded as a benign tumor, we found nine cases showing lymph node metastasis among the literature [Table 1]. The table surmises major clinical data of ten cases of gangliocytic paraganglioma with lymph node metastasis including the present case were analyzed. Patient age ranged from 17 to 74 (mean: 46.4). Male-to-female ratio was 3:7. Tumor sizes ranged from 14 to $65 \mathrm{~mm}$ (mean: 32.9 ). Nine cases occurred at duodenum, but one occurred at pancreas. Although present patient was older, its location and size follows characteristic manner of the disease. One case had irradiation as an adjuvant therapy [10], no recurrence or distant metastasis, however, was described in all patients who we had extracted from the previously reported cases. Therefore, we decided to avoid any adjuvant therapy from the present case. The results of immunohistochemical examinations are summarized in Table 2 with those of previously reported cases of gangliocytic paraganglioma with lymph node metastasis. In the present case, three identical components were clearly identified by phenotypical expression analysis, which correspond to those previously reported with the exception of positive reactivity for chromogranin A. In addition, the present case also showed lymphatic involvement of tumor cells of an epithelioid cell type at the primary focus and regional lymph node metastasis. Furthermore, there was a study suggesting approximately $5 \%$ of gangliocytic paraganglioma demonstrate malignant behavior [10], an importance of imaging examinations before an operation should be emphasize to determine the most suitable method of surgical intervention [11]. On the other hand, several studies conducting to neuroendocrine tumor have reported that bcl-2 and/or p53 expression might be correlated with malignant behavior of them [2-5], whereas no studies were found of which investigation was limited in gangliocytic paraganglioma.

Therefore, we unfortunately have to conclude an immunohistochemical evaluation using bcl-2 or p53 in gangliocytic paraganglioma has a limited prognostic value mostly due to its rarity. In fact, some studies indi- 


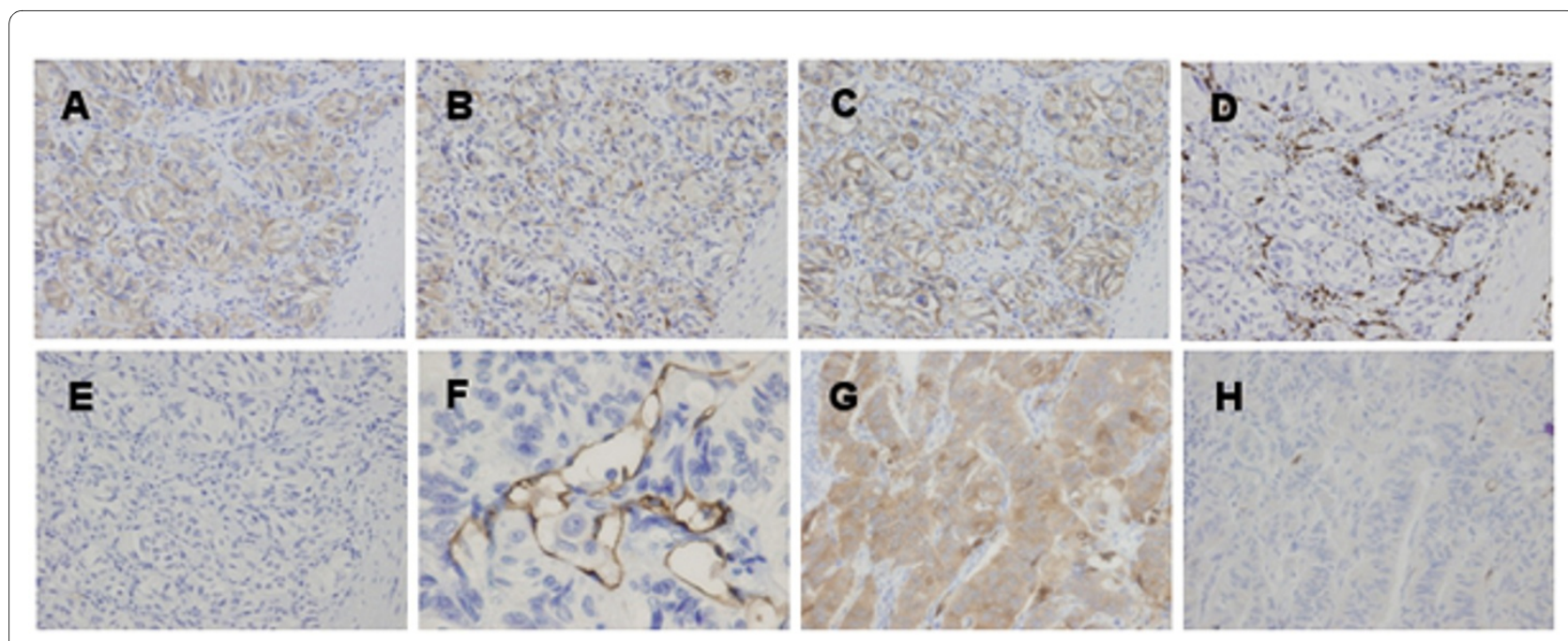

Figure 3 Photomicrographs showing representative immunohistochemistry. ( $A, B$, and C) Epithelioid cells showed positive reactivity for synaptophysin, somatostatin, and CD56 ( $\times$ 400). (D) Spindle-shaped cells showed positive reactivity for S-100 protein $(\times 400)$. (E) Tumor cells of both types showed negative reactivity for chromogranin A ( $\times 400)$. (F) Tumor cells invade into the lymphatic lumen (immunohistochemistry with podoplanin (D2-40) antibody, $\times 400)$. (G) Epithelioid cells metastasizing at the lymph node showed positive reactivity for synaptophysin $(\times 400)$. (H) No spindleshaped cells were found in the metastatic focus as confirmed by the lack of S-100 protein-positive cells ( $\times 400)$.

cated that bcl-2 and/or p53 expression was not correlated with malignant behavior in gastrointestinal neuroendocrine tumors $[12,13]$. In addition, MIB-1 (Ki-67) has been known as a prognostic indicator in neuroendocrine tumor [14]. However, none of previously reported cases of gangliocytic paraganglioma with lymph node metastasis described the MIB-1 (Ki-67) labeling index and that of the present case estimated less than $1 \%$ in both primary and metastatic foci. These finding suggests that immunohistochemical evaluation using MIB-1 (Ki-67) has also a limited prognostic value in gangliocytic paraganglioma.
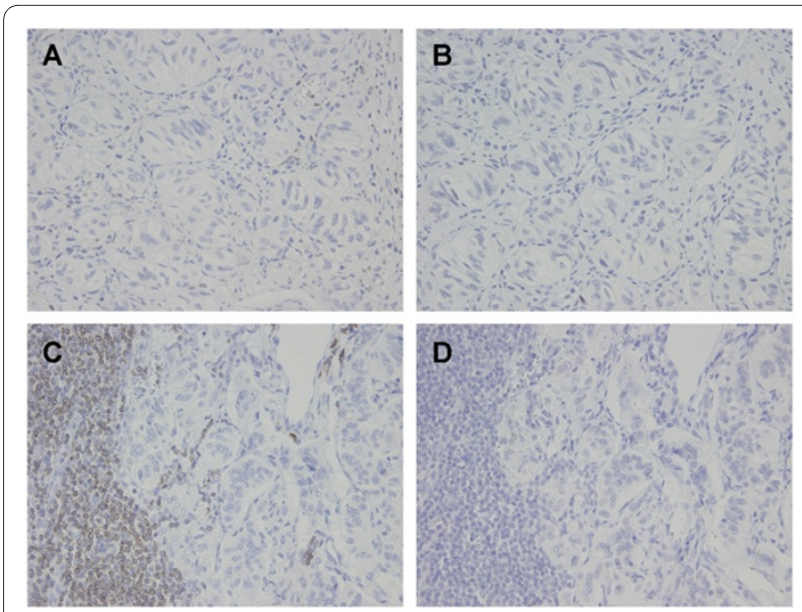

Figure 4 Photomicrographs showing immunohistochemistry for bcl-2 and p53. (A and B) Tumor cells in primary focus showed negative reactivity for both bcl-2 and p53 ( $\times 400)$. (C and D) Tumor cells in metastatic focus showed negative reactivity for both bcl-2 and p53 $(\times 400)$.
In the meantime, Hagemeyer et al. reported the case of pulmonary paraganglioma with p53 expression after Tschernobyl radiation [15]. They suggested that the irradiation had little influence on development of pulmonary paraganglioma, but smoking or irradiation could be associated with p53 expression. A part of their notion may be supported because our patient showed no p53 expression who had history of neither smoking nor irradiation. However, it should be unripe that smoking or irradiation has a relationship to p53 expression of tumor cell in gangliocytic paraganglioma. We wish to emphasize the importance of imaging examinations to monitor for recurrence or metastasis after the operation, because appropriate prognostic indicators have not been accepted using immunohistochemical evaluation.

The operation of our patient resulted in success, and he still maintains a high quality of life six months after that. Neither chemotherapy nor radiation has started because consensus on the adjuvant therapy for this tumor has not been reached at present.

\section{Conclusions}

We describe a case of duodenal gangliocytic paraganglioma showing lymph node metastasis, of which histological and immunohistochemical examinations revealed the tumor comprised three identical cellular components; epithelioid cells, spindle-shaped cells, and ganglion-like cells. Furthermore, the case showed node metastasis despite lack of bcl-2 and p53 expression.

In addition to the rarity of the tumor, we wish to emphasize that the malignant potency of the tumor 
Table 2: Summary of phenotypical expression analysis by immunohistochemical examination

\begin{tabular}{|c|c|c|c|c|c|c|}
\hline & \multicolumn{3}{|c|}{ Literature summary* } & \multicolumn{3}{|c|}{ Present case } \\
\hline & $\begin{array}{c}\text { Epithelioid } \\
\text { cell }\end{array}$ & $\begin{array}{c}\text { Spindle- } \\
\text { Shaped cell }\end{array}$ & $\begin{array}{c}\text { Ganglion-like } \\
\text { cell }\end{array}$ & $\begin{array}{c}\text { Epithelioid } \\
\text { cell }\end{array}$ & $\begin{array}{c}\text { Spindle- } \\
\text { Shaped cell }\end{array}$ & $\begin{array}{c}\text { Ganglion-like } \\
\text { cell }\end{array}$ \\
\hline CD56 & NR & NR & NR & + & - & + \\
\hline Chromogranin A & $4 / 4$ & $0 / 2$ & $1 / 2$ & - & - & - \\
\hline Somatostatin & $3 / 3$ & $0 / 1$ & $2 / 2$ & + & - & + \\
\hline Synaptophysin & $4 / 4$ & $1 / 3$ & $3 / 3$ & + & - & + \\
\hline S-100 & $1 / 2$ & $6 / 6$ & $0 / 2$ & - & + & - \\
\hline CK & $1 / 1$ & NR & NR & - & - & - \\
\hline NF & $1 / 2$ & $2 / 3$ & $1 / 2$ & ND & ND & ND \\
\hline NSE & $3 / 3$ & $3 / 3$ & $2 / 2$ & ND & ND & ND \\
\hline PP & $1 / 2$ & $0 / 1$ & $2 / 2$ & ND & ND & ND \\
\hline bcl-2 & NR & NR & NR & - & - & - \\
\hline p53 & NR & NR & NR & - & - & - \\
\hline
\end{tabular}

CK: Cytokeratin, NF: Neurofilament, NSE: Neuron-specific enolase, PP: Pancreatic polypeptide

NR: Not reported, ND: Not done in the present case.

*: Based on referenced [1,16-19], and [21].

In the present case, three identical components have been clearly identified by phenotypical expression analysis, which corresponds to those previously reported with the exception for chromogranin A. Furthermore, we found lymph node metastasis despite lack of bcl-2 and p53 expression.

despite lack of acceptable prognostic indicators for neuroendocrine tumor.

\section{Consent}

Written informed consent was obtained from the patient for publication of this case report and any accompanying images. A copy of the written consent is available for review by the Editor-in-Chief of this journal.

\section{Abbreviations}

HE: hematoxylin and eosin; EMA: epithelial membrane antigen.

\section{Competing interests}

Dr. Shibuya reports receiving research grants from Pfizer Inc., Janssen Pharmaceutical K.K., and Dainippon Sumitomo Pharma Co. All authors declare that they have no competing interests.

\section{Authors' contributions}

YO conceptualized the case report, integrated the data, and wrote the manuscript as a major contributor; TY carried out the histopathology evaluation and revised histopathological description; MT performed operation and contributed to management of the patient; AM, MW, CH, DS, and TN carried out the histopathologic evaluation; KS gave final approval to the manuscript as a corresponding author. All authors contributed to conceptualizing and writing this case report. Furthermore, all authors read and approved the final manuscript.

\section{Acknowledgements}

This work was supported by the Health Science Research Grants for Research on Emerging and Re-emerging Infectious Diseases (H16-Shinko-6 and H19Shinko-8), Measures for Intractable Diseases (H20 nannchi ippann 35) from the Ministry of Health, Labor and Welfare of Japan, by a Grant of the Strategic Basis on Research Grounds for Non-governmental Schools at Heisei 20th from the Ministry of Education, Culture, Sports, Science and Technology Japan to K. S, and Toho University project grant \#21-24 to Y. O
The authors thank Minoru Shinozaki for his excellent technical support and Tsutomu Hatori, Takayuki Hirano, and Kayoko Shimodaira for their pathological advice.

\section{Author Details}

1Department of Surgical Pathology, Toho University School of Medicine, 6-11-1 Omori-Nishi, Ota-Ku, Tokyo, 143-8541, Japan, 2Department of Pathology, Kanagawa Cancer Center, 1-1-2, Nakao, Asahi-Ku, Yokohama-city, Kanagawa, 245-0815, Japan, ${ }^{3}$ Division of General and Gastroenterological Surgery, Department of Surgery (Omori), Toho University School of Medicine, 6-11-1 Omori-Nishi, Ota-Ku, Tokyo, 143-8541, Japan and 4Department of Pathology, Tokyo Metropolitan Cancer and Infectious Diseases Center, Komagome Hospital, 18-22, Honkomagome 3 chome, Bunkyo-Ku, Tokyo, 113-8677, Japan

Received: 26 March 2010 Accepted: 6 May 2010

Published: 6 May 2010

\section{References}

1. Sundararajan V, Robinson-Smith TM, Lowy AM: Duodenal gangliocytic paraganglioma showing lymph node metastasis: a case report and review of the literature. Arch Pathol Lab Med 2003, 127:139-141.

2. Gal AA, Sheppard MN, Nolen JD, Cohen C: p53, cellular proliferation, and apoptosis-related factors in thymic neuroendocrine tumors. Mod Pathol 2004, 17:33-39

3. de Krijger RR, Harst E van der, Ham F van der, Stijnen T, Dinjens WN, Koper JW, Bruining HA, Lamberts SW, Bosman FT: Prognostic value of p53, bcl2 , and c-erbB-2 protein expression in phaeochromocytomas. J Pathol 1999, 188:51-55.

4. Cadden IS, Atkinson AB, Johnston BT, Pogue K, Connolly R, McCance D, Ardill JE, Russell CF, McGinty A: Cyclooxygenase-2 expression correlates with phaeochromocytoma malignancy: evidence for a Bcl-2dependent mechanism. Histopathology 2007, 51:743-751.

5. Wang DG, Johnston CF, Sloan JM, Buchanan KD: Expression of Bcl-2 in lung neuroendocrine tumours: comparison with p53. J Pathol 1998, 184:247-251.

6. Plaza JA, Vitellas K, Marsh WL Jr: Duodenal gangliocytic paraganglioma: a radiological-pathological correlation. Ann Diagn Pathol 2005, 9:143-147. 
7. Castoldi L, De Rai P, Marini A, Ferrero S, De Luca V, Tiberio G: Neurofibromatosis-1 and Ampullary Gangliocytic Paraganglioma Causing Biliary and Pancreatic Obstruction. Int $J$ Gastrointest Cancer 2001, 29:93-98.

8. Kotsis T, Voros D, Paphiti A, Frangou M, Mallas E: Duodenal gangliocytic paraganglioma as a radiological moving defect. Dig Surg 2000, 17:636-640.

9. Stephens M, Williams GT, Jasani B, Williams ED: Synchronous duodenal neuroendocrine tumours in von Recklinghausen's disease--a case report of co-existing gangliocytic paraganglioma and somatostatinrich glandular carcinoid. Histopathology 1987, 11:1331-1340.

10. Wong A, Miller AR, Metter J, Thomas CR Jr: Locally advanced duodenal gangliocytic paraganglioma treated with adjuvant radiation therapy: case report and review of the literature. World J Surg Oncol 2005, 3: page number not for citation purposes

11. Morita T, Tamura S, Yokoyama Y, Onishi T, Kuratani Y, Mizuta H, Onishi S: Endoscopic resection of a duodenal gangliocytic paraganglioma. Dig Dis Sci 2007, 52:1400-1404

12. Van Eeden S, Quaedvlieg PF, Taal BG, Offerhaus GJ, Lamers CB, Van Velthuysen ML: Classification of low-grade neuroendocrine tumors of midgut and unknown origin. Hum Pathol 2002, 33:1126-1132.

13. Moyana TN, Xiang J, Senthilselvan A, Kulaga A: The spectrum of neuroendocrine differentiation among gastrointestinal carcinoids: importance of histologic grading, MIB-1, p53, and bcl-2 immunoreactivity. Arch Pathol Lab Med 2000, 124:570-576.

14. Pape UF, Berndt U, Müller-Nordhorn J, Böhmig M, Roll S, Koch M, Willich $\mathrm{SN}$, Wiedenmann B: Prognostic factors of long-term outcome in gastroenteropancreatic neuroendocrine tumours. Endocr Relat Cancer 2008, 15:1083-1097.

15. Hagemeyer O, Gabius HJ, Kayser K: Paraganglioma of the lung-developed after exposure to nuclear radiation by the Tschernobyl atomic reactor accident? Respiration 1994, 61:236-239.

16. Inai K, Kobuke T, Yonehara S, Tokuoka S: Duodenal gangliocytic paraganglioma showing lymph node metastasis in a 17-year-old boy. Cancer 1989, 63:2540-2545.

17. Hashimoto S, Kawasaki S, Matsuzawa K, Harada H, Makuuchi M: Gangliocytic paraganglioma of the papilla of Vater with regional lymph node metastasis. Am J Gastroenterol 1992, 87:1216-1218.

18. Takabayashi N, Kimura T, Yoshida M, Sakuramachi S, Harada Y, Kino I: A Case Report of Duodenal Gangliocytic Paraganglioma with Lymph Node metastasis. The Japanese Society of Gastroenterological Surgery 1993, 26:2444-2448. (In Japanese)

19. Tomic S, Warner T: Pancreatic somatostatin-secreting gangliocytic paraganglioma showing lymph node metastases. Am J Gastroenterol 1996, 91:607-608.

20. Bucher P, Mathe Z, Bühler L, Chilcott M, Gervaz P, Egger JF, Morel P: Paraganglioma of the ampulla of Vater: a potentially malignant neoplasm. Scand J Gastroenterol 2004, 39:291-295.

21. Witkiewicz A, Galler A, Yeo CJ, Gross SD: Gangliocytic paraganglioma: case report and review of the literature. J Gastrointest Surg 2007 11:1351-1354.

22. Mann CM, Bramhall SR, Buckels JA, Taniere P: An unusual case of duodenal obstruction-gangliocytic paraganglioma. J Hepatobiliary Pancreat Surg 2009, 16:562-565.

doi: 10.1186/1746-1596-5-27

Cite this article as: Okubo et al., Duodenal gangliocytic paraganglioma showing lymph node metastasis: A rare case report Diagnostic Pathology $2010,5: 27$

Submit your next manuscript to BioMed Central and take full advantage of:

- Convenient online submission

- Thorough peer review

- No space constraints or color figure charges

- Immediate publication on acceptance

- Inclusion in PubMed, CAS, Scopus and Google Scholar

- Research which is freely available for redistribution

Submit your manuscript at www.biomedcentral.com/submit
C Biomed Central 